Volume 2 Nomor 1, Januari-Juni 2018: hlm. 21-32. Magister Ilmu Hukum, Fakultas Hukum, Universitas Lampung, Bandar Lampung, Lampung, Indonesia.

E-ISSN: 2598-3105 P-ISSN: 2723-2581

http://jurnal.fh.unila.ac.id/index.php/cepalo
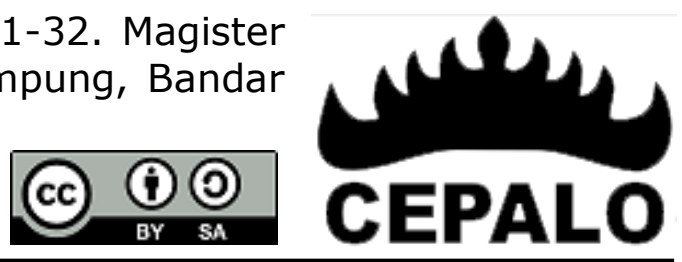

\title{
ANALISIS HUKUM TERHADAP TANGGUNG JAWAB JASA TUKANG GIGI MENURUT PERATURAN MENTERI KESEHATAN NOMOR 39 TAHUN 2014 TENTANG PEMBINAAN PENGAWASAN DAN PERIZINAN PEKERJAAN TUKANG GIGI
}

\author{
LEGAL ANALYSIS OF DENTAL SERVICE RESPONSIBILITIES ACCORDING TO THE \\ MINISTER OF HEALTH REGULATION NO. 39 OF 2014 CONCERNING \\ DEVELOPMENT OF SUPERVISION AND LICENSING OF \\ DENTAL WORKERS \\ Anisa Nurlaila Sari \\ Magister Ilmu Hukum Universitas Lampung \\ anisa.nurlailasari@yahoo.com
}

\begin{abstract}
Abstrak
Tukang gigi merupakan seseorang yang memiliki keahlian memasang dan membuat gigi palsu lepas pasang. Kewenangan tukang gigi dimuat dalam Peraturan Menteri Kesehatan Nomor 39 Tahun 2014 tentang Pembinaan Pengawasan dan Perizinan Pekerjaan Tukang Gigi. Pada prakteknya tukang gigi tidak sekedar memasang dan membuat gigi palsu lepas pasang beberapa gigi atau seluruh gigi dimana gigi palsu tersebut terbuat dari bahan heat curing acrylic. Namun dalam praktiknya tukang gigi tersebut dalam melakukan pekerjaan sering tidak selaras dengan aturan yang berlaku, seperti pemasangan alat kawat gigi. Pekerjaan yang dilakukan jasa tukang gigi telah melebihi wewenang yang ditetapkan, dan tidak sesuai dengan kompetensi yang dimilikinya sehingga diperlukan perlindungan hukum bagi konsumen maupun bagi tukang gigi agar dalam melakukan pekerjaan dapat terlindungi. Dalam penulisan ini peneliti menggunakan penelitian hukum empiris. Data yang digunakan ialah data primer dan sekunder.Dalam menganalisa data yang digunakan dalam penelitian ini yaitu analisis data kualitatif.
\end{abstract}

Kata Kunci: Jasa, Tukang Gigi, Tanggung Jawab

\begin{abstract}
A dentist is someone who has the expertise to install and make removable dentures. The authority of dental artisans is contained in the Minister of Health Regulation No. 39 of 2014 concerning Guidance for Supervising and Licensing of Dental Workers. In practice, dental artisans do not just install and make dentures remove pairs of teeth or entire teeth where the dentures are made of heat curing acrylic. But in practice the dental artisan in doing work is often not in line with applicable regulations, such as the installation of braces. The work performed by dental artisan services has exceeded the established authority, and is not in accordance with its competence, so that legal protection is needed for consumers and for dental artisans so that the work can be protected. In this paper the researcher uses empirical legal research. The data used are primary and secondary data. In analyzing the data used in this study is qualitative data analysis.
\end{abstract}

Keywords: Service, Dentist, Responsibility

Cara Mengutip (How to Cite): Anisa Nurlaila Sari, “Analisis Hukum Terhadap Tanggung Jawab Jasa Tukang Gigi Menurut Peraturan Menteri Kesehatan Nomor 39 Tahun 2014 tentang Pembinaan Pengawasan dan Perizinan Pekerjaan Tukang Gigi”, Jurnal Cepalo, 2 (1), (2018): 21-32. 
DOI: https://doi.org/10.25041/cepalo.v2no1.1759

\section{A. Pendahuluan}

Manusia atau orang merupakan suatu makhluk sosial yang membutuhkan orang lain dalam rangka saling memberi suatu keuntungan satu sama lain. Maka dari itu dalam memenuhi kehidupan yang sehat baik kesehatan jasmani maupun kesehatan rohani, mereka membutuhkan bantuan orang lain yang ahli. Kesehatan jasmani merupakan hal yang paling berharga dalam kehidupan. Kesehatan merupakan suatu kebutuhan yang sangat penting bagi manusia sebagai makhluk sosial selain memenuhi hak dan kewajiban. Apabila manusia dalam keadaan sehat maka segala aktivitas yang ia jalani akan berjalan dengan baik. Seiring bekembangnya zaman dan kemajuan teknologi saat ini memberi pengaruh cukup besar dalam kehidupan manusia. Salah satunya dalam bidang kesehatan, begitu banyak praktik kesehatan yang dilakukan oleh para dokter dan tenaga kesehatan lainnya, seperti pengobatan tradisional yang kini marak di masyarakat. Kesehatan gigi dan mulut adalah salah satu bidang kesehatan yang terkadang dilupakan manusia, manusia beranggapan bahwa kesehatan gigi dan mulut bukan suatu prioritas dalam kesehatan. Padahal kesehatan gigi dan mulut sama pentingnya dengan kesehatan lainnya.

Penanganan yang tepat dalam mencegah ataupun menangani masalah pada kesehatan gigi dan mulut harus dengan ahlinya yaitu dokter gigi. Dokter gigi dianggap mampu untuk melakukan pemulihan kesehatan gigi dan mulut. Anggapan yang timbul di masyarakat ialah tidak terjangkaunya oleh masyarakat kelas menengah kebawah. Sehingga tukang gigi menjadi alternatif pengobatan bagi masyarakat kelas menengah kebawah. Jasa tukang gigi merupakan pelayanan kesehatan yang dikategorikan dalam kesehatan tradisional karena keterampilannya dipelajari secara turun temurun. Keberadaan tukang gigi dapat dijadikan jalan alternatif bagi masyarakat untuk dapat pelayanan kesehatan gigi yang murah. Akan tetapi, tukang gigi merupakan salah satu dari begitu banyaknya praktik kesehatan yang sering kali tidak terdapat izin berpraktik.

Permenkes Nomor 39 Tahun 2014 Pasal 1 ayat (1), tukang gigi adalah setiap orang yang memiliki keahlian membuat dan memasang gigi tiruan lepas pasang. Pekerjaan tukang gigi di Indonesia sudah ada sejak zaman Belanda. Bahkan tukang gigi (tandmeester), yang pada saat itu dikenal sebagai dukun gigi sudah memonopoli pasar. ${ }^{1}$ Peran pemerintah dalam mengawasi keberadaan tukang gigi adalah dengan menerbitkan Permenkes No. 53 Tahun 1969 tentang Pendaftaran dan Pemberian Izin Menjalankan Profesi Tukang Gigi. Dalam Peraturan Menteri Kesehatan berisi tata cara pencatatan serta penyerahan izin dalam melakukan profesi tukang gigi, regulasi ini diterbitkan atas dasar pertimbangan, dimana pada saat itu di Indonesia sendiri masih ramai yang melakukan profesi di ranah kesehatan tidak mempunyai pengalaman ilmiah yang dibutuhkan dan melaksanakan pekerjaan di luar batas- kewenangan dan keahliannya yang dikhawatirkan dapat membahayakan dan merugikan kesehatan masyarakat.

Peraturan tersebut diganti dan diterbitkannya Permenkes Nomor 339/MENKES/PER/V/1989 tentang Pekerjaan Tukang Gigi, diterbitkannya regulasi itersebut dengan dasar bahwa, usaha pengobatan menurut ilmu atau cara lain dari pada ilmu kedokteran, yang diawasi oleh pemerintah supaya tidak mengkhawatirkan kesehatan masyarakat. Penarikan tersebut berakibat pada tidak dikeluarkannya izin berpraktik hingga tidak ada perpanjangan izin praktik tukang gigi. Penarikan izin tersebut didasarkan pada Pasal 73 ayat (2) Undang-Undang Nomor 29 Tahun 2004 tentang Praktik Kedokteran. Kemudian dipertegas oleh Pasal 78 Undang-Undang Nomor 24 Tahun 2004 tentang Praktik Kedokteran. Namun pada tahun 2012 dilakukan uji materiil terhadap Undang-Undang Praktik Kedokteran tersebut ke Mahkamah Konstitusi. Putusan Mahkamah Konstitusi Nomor 40/PUU- X/2012 akhirnya menurunkan perubahan pemaknaan pada Pasal 73 ayat (2) dan Pasal 78 Undang- Undang Praktik Kedokteran sehingga berakibat pembatalan Peraturan Menteri Kesehatan Nomor 1871/MENKES/PER/IX/2011 tentang Pencabutan Peraturan Menteri Kesehatan Nomor 339/PER/MENKES/V/1989 yang tidak memperpanjang atau tidak memberikan izin kepada

\footnotetext{
${ }^{1}$ www.beritasatu.com/nasib-tukang-gigi/47915-inilah-sejarah-tukang-gigi-di-indonesia.html.
} 
tukang gigi dalam melakukan praktiknya.

Dalam Putusan Mahkamah Konstitusi diatas akan mengeluarkan izin kembali membuka praktek selama yang bersangkutan mempunyai izin dari aparat. Putusan tersebut menjadi pro dan kontra di kalangan tukang gigi, dokter gigi hinnga di kalangan masyarakat luas. Menurut hasil para peneliti di Kota Bandar Lampung terdapat kurang lebih 58 tukang gigi yang tersebar di wilayah Bandar Lampung. Dari 58 tukang gigi, diantaranya tidak mempunyai surat izin praktek dari pemerintah kota. Selain perihal perizinan, Tukang gigi mempunyai batas kewenangan yang telah di terbitkan oleh Permenkes Nomor 39 Tahun 2014 tentang Pembinaan, Pengawasan, dan Perizininan Pekerjaan Tukang gigi. Menurut Pasal 6 ayat (2) pekerjaan yang boleh dilakukan oleh tukang gigi hanya berupa membuat gigi tiruan lepasan sebagian dan/atau penuh yang terbuat dari bahan heat curing acrylic ${ }^{2}$ yang menjalankan ketentuan persyaratan kesehatan, dan memasang gigi tiruan lepasan sebagian atau penuh yang terbuat dari bahan heat curing acrylic dengan tidak menutupi bagian akar gigi. Namun realita saat ini tukang gigi tidak hanya membuat dan memasang gigi tiruan lepasan saja tetapi menawarkan pemasangan kawat gigi. Jasa gigi dan mulut dilakukan guna memelihara dan meningkatkan kesehatan dalam bentuk upaya memelihara kesehatan gigi berupa pencegahan penyakit gigi, pengobatan penyakit gigi, dan pemulihan kesehatan gigi oleh pemerintah, pemerintah daerah, dan atau masyarakat yang dilakukan secara terpadu, terintegrasi dan berkesinambungan. ${ }^{3}$ Persoalan perawatan gigi dengan tidak menggunakan jasa pada ahlinya dikhawatirkan akan timbul masalah pada kesehatan gigi dan mulut dari konsumen pengguna jasa tersebut. Namun masyarakat pun buta akan aturan, kemampuan, dan kewenangan tukang gigi.

Hak tukang gigi menjadi lebih luas, karena terdapatnya keinginan dari konsumen untuk melakukan pemasangan kawat gigi, yang seharusnya hanya boleh dilakukan oleh dokter spesialisnya saja. Hal tersebut menghasilkan suatu pendapat bahwa diperlukannya pengaturan hukum yang bisa melindungi konsumen yaitu pemakai jasa tukang gigi guna memberikan rasa aman ketika konsumen menggunakan pelayanan kesehatan ke tukang gigi serta perlindungan untuk konsumen apabila dirugikan akibat dari malapraktik tukang gigi tersebut. Perlindungan konsumen merupakan suatu bagian yang tidak terpisahkan dari kegiatan bisnis yang sehat, dalam kegiatan bisnis yang sehat terdapat keselarasan antara perlindungan hukum konsumen dengan pelaku usaha. Tidak adanya perlindungan yang seimbang dapat menyebabkan konsumen berada pada posisi yang lemah, karena sering kali konsumen merasa dirugikan oleh pelaku usaha sebagai akibat adanya hubungan hukum, maupun akibat adanya perbuatan melawan hukum yang dilanggar oleh pelaku usaha. Kondisi konsumen yang banyak dirugikan tersebut, memerlukan pengembangan upaya untuk melindungi, sehingga hak-hak konsumen juga dapat ditegakkan. Namun sebaliknya memberikan perlindungan kepada konsumen, justru tidak boleh merugikan usaha produsen. ${ }^{4}$ Oleh karena itu konsumen pengguna jasa dilindungi oleh Peraturan Perundang-undangan Nomor 8 Tahun 1999 tentang Perlindungan Konsumen, Undang-Undang Nomor 29 tahun 2004 tentang Praktik Kedokteran, dan Undang-Undang Nomor 36 Tahun 2009 tentang Kesehatan, Undang-Undang Nomor 32 Tahun 2014 tentang Tenaga Kesehatan.

Manakala dalam penggunaan jasa tukang gigi seperti memasang kawat gigi, atau profesi lain di luar dari wewenang yang telah ditetapkan oleh konsumen dan konsumaen merasa dirugikan, maka tukang gigi harus mengganti rugi kepada konsumen tersebut. Ganti rugi yang diberikan dapat berupa pengembalian uang atau penggantian barang dan atau jasa yang sejenisnya yang setara nilainya, atau perawatan kesehatan atau pemberian santunan bagi

\footnotetext{
${ }^{2}$ Head curing acrylic (resin akrilik) merupakan salah satu bahan basis gigi tiruan yang proses polimerisasinya dengan pengaplikasian panas. Bahan ini memiliki keunggulan yaitu mudah diproses dan dipoles, elastis, biaya terjangkau, dan toksisitasnya rendah. Iin sundari, Pocut aya Sofya, dan Milati Hanifa, Studi Kekuatan FleksuralAntara Resin Akrilik Heat Cured dan Termoplastik Nilon Setelah Direndam Dalam Minuman Kopi Uleekareng (Coffe Robusta), Universitas Syia Kuala, 2016.

${ }^{3}$ Lendrawati, Motivasi Masyarakat Dalam Memelihara dan Mempertahankan Gigi, Fakultas Kedokterran Gigi Universitas Andalas Padang, hlm. 91.

${ }^{4}$ Ahmadi Miru, Prinsip-prinsip Perlindungan Hukum Bagi Konsumen di Indonesia, Jakarta: Raja Grafindo Persada, (2013), hlm. 1-2.
} 
konsumen. ${ }^{5}$ Upaya pemerintah untuk melindungi konsumen dari barang atau jasa yang dapat merugikan ialah dengan cara mengatur, mengawasi, mengendalikan produksi, distribusi, dan peredaran produk sehingga konsumen tidak merasa dirugikan, baik kesehatannya maupun keuangannya. ${ }^{6}$ Jika dalam melakukan pekerjaan tukang gigi melanggar ketentuan-ketentuan yang telah diterbitkan oleh Permenkes Nomor 39 Tahun 2014 tentang Pembinaan, Pengawasan, dan Perizinan Pekerjaan Tukang Gigi, maka akan dikenakan sanksi administratif oleh pemerintah daerah Kabupaten/Kota yaitu berupa surat teguran, pencabutan izin sementara, dan pencabutan izin tetap.

Pengawasan gterhadap hukum tersebut dapat bertentangan dengan hak dan kewajiban dari masing-masing pihak dalam hal ini konsumen sebagai pengguna jasa dan tukang gigi sebagai pelaku usaha serta perlindungan hukum baik yang bersifat preventif maupun bersifat represif. Pengobatan yang dilakukan dalam peraktik tukang gigi terkadang tidak menjadi perhatian yang menarik untuk dikaji lebih dalam lagi sehingga terlepas dari perhatian dari banyak pihak khususnya yang berkaitan dengan perlindungan hukum dalam pelaksanaan praktik tukang gigi. Jenis penelitian yang digunakan dalam penelitian ini adalah penelitian hukum empiris. Penelitian ini mengutamakan data primer dan sekunder. Metode pengumpulan data dengan wawancara mendalam, observasi dan studi pustaka. Analisis data yang digunakan yaitu analisis data kualitatif.

\section{B. Pembahasan}

\section{Tanggung Jawab Tukang Gigi Atas Pelanggaran Praktik Yang Menimbulkan Kerugian Kepada Konsumen Menurut Undang-Undang}

Kehadiran tukang gigi di Indonesia berkembang pesat setiap harinya. Tukang gigi merupakan Profesi yang menggunakan cara tradisional dalam bidang kesehatan gigi. Tukang gigi memiliki suatu upaya penyembuhan dan pemeliharaan dengan cara dan alat yang hampir serupa dengan dokter gigi tanpa didasari ilmu kedokteran gigi, sehingga sangat beresiko merugikan kesehatan Gigi para konsumennya. Tukang gigi dalam melakukan pekerjaan, telah diatur oleh Permenkes Nomor 39 Tahun 2014 tentang Pembinaan, Pengawasan dan Perizinan Pekerjaan Tukang Gigi. Mengenai penerapan profesi tukang gigi terdapat dalam Pasal 6, yaitu:

a. Pekerjaan tukang gigi hanya dapat dilakukan apabila:

1) tidak membahayakan kesehatan, menyebabkan kesakitan dan kematian;

2) tidak bertentangan dengan upaya peningkatan derajat kesehatan masyarakat; dan

3) tidak bertentangan dengan norma dan nilai yang hidup di masyarakat.

b. Pekerjaan tukang gigi sebagaimana dimaksud pada ayat (1), hanya berupa:

1) Membuat dan memasang gigi tiruan lepasan sebagian dan/atau penuh yang terbuat dari bahan heat curing acrylic yang memenuhi persyaratan kesehatan; dan

2) Memasang gigi tiruan lepasan sebagian dan/atau penuh yang terbuat dari bahan heat curing acrylic dengan tidak menutupi sisa akar gigi.

Sebagaimana telah dijelaskan di atas, bahwa kewenangan tukang gigi dalam melakukan praktik upaya kesehatan masyarakat hanya membuat dan memasang gigi replika lepasan. Namun pada realitasnya, masih begitu banyak tukang gigi mengerjakan, pekerjaannya di luar kewenangan yang telah ditetapkan. Salah satu pekerjaan yang dilakukan tukang gigi yaitu menawarkan memasang kawat gigi. Dalam memasang kawat gigi yang dilakukan oleh tukang gigi termasuk praktik ilegal karena telah melanggar peraturan yang berlaku. Berdasarkan hasil penelitian penulis, maka penulis mengambil 7 narasumber yang bekerja sebagai tukang gigi.

Narasumber tersebut memberikan informasi terkait dengan pekerjaan apa saja yang dapat dilakukan dalam praktiknya. "Bahwa ia kurang lebih 10 tahun sudah menggeluti pekerjaan sebagai tukang gigi hingga saat ini. Ia mengaku bahwa keterampilan didapat secara turun

\footnotetext{
${ }^{5}$ Kasmawati, "Perlindungan Hukum Bagi Konsumen Terhadap Tegangan Tinggi Listrik di Bandar Lampung", Fiat Justisia Jurnal Ilmu Hukum Unila, Vol. 7 No.4, (2013).

${ }^{6}$ Janus Sidabalok, Hukum Perlindungan Konsumen di Indonesia, Citra Aditya Bakti, (2010), hlm. 23-24.
} 
temurun dan mengikuti pelatihan. Ketika ditanya mengenai aturan terkait dengan pekerjaan sebagai tukang gigi, ia mengatakan bahwa ia mengetahui dan pernah membaca aturan tersebut. Pekerjaan yang dapat ia lakukan selain membuat dan memasang gigi tiruan lepasang, ia kerap kali diminta oleh konsumen untuk memasang kawat gigi. Namun ia menepis jika pemasangan kawat gigi yang dilakukan hanya untuk fashion. Ia menjelaskan pemasangan kawat gigi yang dilakukan adalah kawat gigi perawatan yang berfungsi merapihkan gigi. Disinggung mengenai izin, ia mengaku tidak memiliki izin selama bekerja sebagai tukang gigi, ia hanya memiliki serifikat yang didapat melali pelatihan yang diadakan di Jakarta oleh Dokter Gigi Indonesia. Saat ditanyakan mengenai selama melakukan pekerjaan apakah pernah terjadi suatu masalah pada konsumen seperti pembengkakan atau infeksi, ia menjawab pernah mengalami keluhan dari konsumen yang mengalami pembengkakan, namun masalah itu bisa diatasi. Tetapi tidak pernah ada tuntutan dari konsumen terkait dengan jasa yang diberikan.“

Narasumber kedua yaitu $\mathrm{AH}$, yang namanya tidak mau dipublikasikan mengungkapkan: "bahwa ia telah melakukan pekerjaan sebagai tukang gigi selama 4 tahun, keahliannya tersebut didapatkan secara turun temurun. Terkait aturan mengenai tukang gigi, ia mengaku bahwa ia tidak mengetahui aturan yang terkait dengan pekerjaannya. Pekerjaan yang dilakukan oleh AH bukan hanya membentuk dan memasang gigi replika lepasan saja, tetapi ia juga dapat memasang kawat gigi, vaneer gigi atau pewarnaan pada gigi. Dalam melakukan pekerjaan ia tidak memiliki izin dari Dinas Kesehatan setempat. Ia mengaku bahwa ia hanya meneruskan pekerjaan orang tuanya yang dahulunya bekerja sebagai tukang gigi. Menurut pengakuannya sudah banyak konsumen yang melakukan perawatan gigi kepadanya dan sampai saat ini tidak ada yang mengeluh kekecewaan dari hasil pekerjaannya. Selama melakukan pekerjaan ia tidak pernah mendapatkan keluhan ataupun tuntutan dari konsumen yang menggunakan jasanya."

Narasumber tukang gigi yang ketiga adalah AY, menyatakan: ÁY menyatakan, ia telah 3 tahun menggeluti pekerjaan sebagai tukang gigi, selama melakukan pekerjaannya ia bisa memenuhi panggilan dari rumah ke rumah selama jarak yang ditempuh masih terjangkau. Ketika peneliti memberi pertanyaan mengenai peraturan yang berkaitan dengan pekerjaannya sebagai tukang gigi dan kewenangan yang dapat dilakukan, ia mengaku pernah mendengar peraturan itu, namun tidak mempelajarinya secara mendalam. Pekerjaan yang bisa ia lakukan diantaranya bisa melakukan pembuatan gigi palsu dan pemasangan gigi palsu. Tetapi beberapa tahun belakangan ini banyak permintaan dari konsumen untuk dapat memasangkan kawat gigi, terlebih trend terbaru yang saat ini adalah vaneer gigi pewarnaan gigi). Disinggung mengenai izin praktik, ia mengaku tidak memiliki izin secara resmi dari pemerintah daera setempat. Peneliti juga menanyakan apakah selama ia melakukan pekerjaan pernah ada Dinas Kesehatan setempat yang melakukan pengawasan terkait dengan pekerjaannya, ia menjawa tidak pernah ada pengawasan yang dilakukan. Selanjutnya peneliti menanyakan apakah pernah ada keluhan dari konsumen, AY mengatakan sampai saat ini banyak respon yang baik darikonsumennya."

Narasumber keempat yaitu AN mengungkapkan: Telah melakukan pekerjaan ini cukup lama, sudah banyak konsumen yang datang untuk melakukan perawatan gigi. Ia mengaku bahwa keahlian tersebut didapat secara turun temurun. Ketika peneliti menanyakan apakah ia mengetahui aturan terkait dengan tukang gigi, ia tidak memahami akan adanya aturan tentang tukang gigi yang dikeluarkan oleh pemerintah. Jenis perawatan yang dapat dilayani mulai dari pembuatan gigi palsu, pemasangan gigi palsu, pembersihan karang gigi, serta pemasangan kawat gigi. terlebih diakuinya ketika trend kawat gigi sedang populer, banyak sekali yang datang untuk memasangkan kawat gigi. kebanyakan dari mereka adalah para remaja, mahasiswa, tetapi ada juga orang dewasa. Ketika ditanya mengenai izin, AN mengakui bahwa ia tidak memiliki izin dari Dinas Kesehatan setempat, yang ia miliki hanya izin usaha. Ketika ditanya apakah ada pengawasan rutin yang dilakukan oleh Dinas Kesehatan setempat, ia mengungkapkan tidak ada pengawasan yang dilakukan. Peneliti juga menanyakan apakah selama melakukan pelayanan jasa kepada konsumen pernah ada keluhan ketidakpuasan dan tuntutand ari konsumen, ia mengaku tidak pernah ada tuntutan, keluhan sempat ada dari pemasangan kawat gigi yang mengaku merasa tidak nyaman, namun saya bertanggung jawab untuk memperbaiki pemasangan tersebut."

Narasumber yang kelima yaitu IW mengungkapkan: "IW telah menjadi tukang gigi sejak 
tahun 2010, ia meneruskan pekerjaan yang dilakukan oleh ayahnya. Ayahnya dahulu bekerja sebagai tukang gigi, dan ia diajarkan serta dikuti seminar-seminar yang berkaitan dengan tukang gigi. Sehingga setelah dirasa bisa, ia meneruskan pekejaan ayahnya sebagai tukang gigi. Setiap pelatihan diajarkan tentang berbagai masalah pembuatan gigi, bahan yang digunakan, serta takaran bahan yang digunakan dalam pembuatan gigi palsu. Selain itu diajarkan mengenai pemasangan gigi palsu. Beberapa tahun belakangan ini pun saya belajar mengenai pemasangan kawat gigi, dan sudah banyak yang memasang kawat gigi kepada saya. Ketika ditanya apakah ia mengetahui aturan terkait dengan pekerjaannya sebagai tukang gigi, ia menjawab tidak mengetahui aturan tersebut. Untuk perizinan pemerintah atau Dinas Kesehatan setempat ia mengaku tidak ada izin resmi dari Dinas Kesehatan. Selain itu peneliti menanyakan apakah ada pengawasan rutin yang dilakukan oleh Dinas Kesehatan, IW mengungkapkan samapai saat ini belum ada pengawasan yang dilakukan oleh Dinas Kesehatan setempat. Kemudian peneliti juga menanyakan apakah selama melakukan pekerjaan sebagai tukang gigi pernah mendapatkan tuntutan atau keluhan dari konsumen, IW menjawab tidak pernah ada tuntutan ataupun keluhan dari konsumen, rata-rata konsumen merasa puas dan kebanyakan kembali lagi untuk melakukan perawatan.

Narasumber keenam yaitu RD mengungkapkan: "Telah melakukan pekerjaan cukup lama, dan sudah mempunyai konsumen tetap yang membuat dan memasang gigi tiruan kepadanya. Ketika penelit menanyakan bagaimana keahliannya didapat, RD mengungkapkan bahwa ia memperolehnya secara turun temurun. Selanjutnya peneliti juga menanyakan apakah mengetahui aturan yang terkait dengan pekerjaannya, RD mengungkapkan tidak mengetahui.

Narasumber ketujuh AD mengungkapkan:

"Belum lama melakukan pekerjaan ini, sekitar 5 tahun belakangan ini. AD mengungkapkan bahwa ia mendapatkan keahliannya secara turun temurun. AD mengetahui aturan terkait dengan pekerjaanya. Jenis perawatan yang dilayani oleh AD yaitu merancang dan memasang gigi replika lepasan. Selain itu beliau menjelaskan dapat melayani perawatan gigi seperti pembersihan karang gigi dan pemasangan kawat gigi. AD mengakui bahwa ia tidak memiliki izin dari Dinas Kesehatan setempat. Selanjutnya peneliti menanyakan apakah ada keluhan atau tuntutan dari konsumen terkait dengan pekerjaannya, AD menjawab untuk keluhan tentu ada, namun bisa diatasi. Keluhan biasanya hanya ketidaknyamanan pemasangan gigi, namun setela diperbaiki konsumen tidak ada keluhan lagi. Mengenai tuntutan, tidak pernah ada tuntutan dari konsumen. AD mengatakan selama ia melakukan pekerjaan bahwa tidak pernah ada pengawasan dari Dinas Kesehatan terkait dengan pekerjaannya."

Berdasarkan informasi yang diberikan oleh tujuh narasumber, maka dapat disimpulkan bahwa dari tujuh narasumber yang telah ditemui, semua mengatakan bahwa keahliannya didapatkan secara turun temurun. Hanya beberapa dari mereka yang mengetahui aturan terkait dengan pekerjaannya sebagai tukang gigi. Jenis perawatan yang dapat dilakukan oleh ke tujuh narasumber di atas di luar batas kewenangan dan mereka tidak memiliki izin dari pemerintah setempat atau Dinas Kesehatan setempat seperti yang sudah ditetapkan oleh Permenkes Nomor 39 Tahun 2014 tentang Pembinaan, Pengawasan dan Perizinan Profesi Tukang gigi. Apabila tukang gigi menjalankan pekerjaan kepada konsumen dan menyebabkan kerugian, maka tukang gigi wajib memberikan sebuah ganti rugi terhadap konsumen. Sesuai dengan ketentuan dalam Pasal 19 Undang-Undang Nomor 8 Tahun 1999 tentang Perlindungan Konsumen. Jika pelaku usaha enggan memberikan ganti rugi atas tuntutan konsumen sebagaimana dimaksud dalam Pasal 19 ayat (1), ayat (2), ayat (3) dan ayat (4) Undang- Undang Nomor 8 Tahun 1999 tentang Perlindungan Konsusmen, maka dapat digugat melalui badan penyelesaian sengketa konsumen atau mengajukan ke badan peradilan di tempat kedudukan konsumen. Sanksi dari peraturan lainnya itu pada Pasal 58 Undang-Undang Nomor 36 tahun 2009 tentang Kesehatan, menyatakan bahwa setiap orang berhak menuntut ganti rugi terhadap seseorang, tenaga kesehatan, dan/atau penyelenggara kesehatan yang menimbulkan kerugian akibat kesalahan atau kelalaian dalam pelayanan kesehatan yang diterimanya.

\section{Tanggung Jawab Tukang Gigi sebagai Pemberi Jasa Terhadap Pengguna Jasa}

Keberadaan tukang gigi sebenarnya sudah ada sejak jaman penjajahan Belanda yang saat 
itu dikenal sebagai dukun gigi sudah memonopoli pasar. Jika dilihat dari segi harganya, maka tukang gigi menawarkan harga terjangkau untuk masyarakat yang ingin membuat dan memasang gigi. Berbeda dengan penyembuhan yang dilakukan oleh dokter gigi yang memiliki harga relatif mahal. Saat ini masyarakat lebih cenderung memilih sesuatu dengan harga yang terjangkau dari pada mereka harus membayar dengan harga yang mahal. Peneliti telah melakukan wawancara terhadap 7 (tujuh) narasumber pengguna jasa tukang gigi.

Narasumber pertama yaitu TT, mengungkapkan: "Ia mengungkapkan bahwa ia telah beberapa kali datang ke tukang gigi untuk melakukan penyembuhan gigi dan mulut khususnya perawatan kawat gigi. Ketika peneliti menyinggung apakah TT mengetahui atauran terkait dengan pekerjaan tukang gigi, ia menjawab tidak mengetahui aturan tersebut. Sehingga ia tidak mengetahui batasan atau kewenangan apa saja yang dapat dilakukan oleh tukang gigi dalam melakukan pekerjaannya. TT juga mengungkapkan alasan ia melakukan perawatan ortodonti di tukang gigi karena pemasangan yang dilakukan oleh tukang gigi prosesnya lebih cepat dan harga yang ditawarkan cukup murah dibandingkan dengan dokter gigi. Jenis kawat yang digunakan hanya sekedar fashion. Jika bosan, TT dapat melepasnya sendiri. Jenis kawat gigi yang digunakan merupakan jenis kawat gigi bongkar pasang. Menurut TT memasang di dokter ataupun di tukang gigi sama saja. Selama ia datang dan memperoleh pelayanan dari tukang gigi ia mengungkapkan bahwa ia merasa aman dan tidak pernah timbul gejala atau risiko dari pemasangan yang dilakukan oleh tukang gigi".

Narasumber yang kedua yaitu NND mengungkapkan: "Ia kerap kali mendatangi tukang gigi untuk melakukan perawatan ortodonti, khususnyapemasangan kawat gigi. Ia tertarik melakukan pemasangan kawat gigi karena melihat temannya menggunakan kawat gigi di dokter gigi. Namun karena keterbatasan uang yang dimiliki ia memutuskan untuk memasang kawat gigi dengan harga yang murah. Kemudian disarankan oleh salah satu temannya untuk mengenakan kawat gigi di tukang gigi, karena harganya lebih murah berkisar Rp. 150.000-Rp. 300.000. Tertarik dengan harga yang murah ia memutuskan menggunakan kawat gigi tersebut. NND menggunakan kawat gigi dengan alasan fashion bukan nilai dari kemanfaatan kawat gigi tersebut yaitu untuk merapihkan gigi. Pada saat peneliti menanyakan apakah ia mengetahui perbedaan antara dokter gigi dengan tukang gigi, serta peraturan yang terkait dengan tukang gigi, ia menjawab mungkin dilihat dari segi pendidikannya yang membedakan. Aturan yang terkait NND tidak pernah mengetahuinya. Selama menggunakan jasa tukang gigi ia merasa aman dan tidak takut sama sekali. Selain itu selama ia menggunakan kawat gigi pada tukang gigi tidak ada risiko yang dialami, hanya saja mungkin terasa sakit pada gigi ketika awal menggunakan kawat gigi"

Narasumber ketiga yaitu CM, ngenyatakan: " $\mathrm{CM}$ sudah mendatangi tukang gigi sebanyak 2 kali, yang pertama menemani temannya yang memasang kawat gigi, dan yang kedua ia memasang kawat gigi. Ia memberikan alasan mengapa ia memilih tukang gigi di bandingkan dengan dokter gigi karena prosesnya cepat. Pemeriksaan yang dilakukan oleh tukang gigi cukup cepat dan dapat langsung dilakukan pemasangan kawat gigi. Penawaran harga dari tukang gigi untuk pemasangan kawat gigi hanya berkisar Rp. 200.000-Rp. 400.000 itu tergantung dari jenis kawat gigi dan bracket. Saya juga ditawarkan jenis kawat gigi untuk fashion atau untuk perawatan merapihkan gigi. Namun kawat gigi perawatan lebih mahal dibandingkan dengan kawat gigi fashion. Jika kawat gigi perawatan, tukang gigi menyarankan untuk melakukan kontrol setiap bulannya untuk melihat perkembangan perawatan yang dilakukan. Ketika peneliti menanyakan apakah mengetahui keahlian yang didapatkan tukang gigi, ia menjawab bahwa sepertinya didapatkan secara turun temurun. Ia tidak mengetahui aturan terkait dengan tukang gigi. CM merasa nyaman dan aman menggunakan jasa tukang gigi.

Narasumber keempat yaitu BB seorang mahasiswa mengungkapkan: "Bahwa ia melakukan pemasangan kawat gigi di tukang gigi. Ia menjelaskan bahwa ia melakukan pemasangan kawat gigi dengan alasan untuk melakukan perawatan gigi yang dinilainya kurang rapih. Tukang gigi dipilih berdasarkan pertimbangan harga yang lebih terjangkau dibandingkan dilakukan didokter gigi. Ia mengungkapkan sebelum ia melakukan pemasangan kawat gigi di tukang gigi ia terlebih dahulu ia melakukan perawatan di dokter gigi. namun karena kekecewaannya dengan dokter gigi ia memilih melakuka perawatan di tukang gigi. 
Kekecewaannya terhadap dokter gigi dinilai karena lamanya proses pemasangan kawat gigi. Padahal ia sudah melunasi sejumlah uang untuk proses pemasangan kawat gigi tersebut. Oleh sebabnya ia menggunakan jasa tukang gigi yang dinilai lebih efektif dalam melakukan perawatan kawat gigi. Ketika ditanyakan ia merasa aman atau tidak ia menjawab ia merasa aman menggunakan jasa tukang gigi. ia disarankan kontrol untuk melihat perkembangan dan penggantian kawat serta bracket seperti yang sama ia lakukan pada dokter gigi".

Narasumber kelima yaitu SA mengungkapkan: "Ia memilih tukang gigi untuk melakukan perawatan gigi, khususnya pemakaian kawat gigi. Menurutnya kawat gigi yang dipasang didokter gigi maupun di tukang gigi sama saja tidak ada perbedaan apapun. Alat yang digunakan pun sama seperti yang ada pada dokter gigi. Mungkin perbedaannya terletak pada harga yang ditawarkannya. Tidak ada resiko ataupun kendala yang pernah ia alami selama ia menggunakan kawat gigi di tukang gigi, hanya saja pada awal pemasangan merasakan linu pada bagian gigi ketika mengunyah makanan. Tetapi untuk selanjutnya tidak ada gejala yang dialami. Selain itu tukang gigi lebih cepat dalam melakukan proses pemasangan kawat gigi.

Narasumber keenam yaitu EH, mengungkapkan: "Ia tertarik dengan penawaran harga kawat gigi yang beraneka ragam. Sehingga ia berniat memasang kawat gigi. Awalnya ia mengungkapkan ingin melakukan pemasangan di dokter, namun ketika ia mencari-cari referensi melalui media sosial, banyak yang menawarkan dengan harga yang begitu jauh lebih murah dari harga pemasangan didokter gigi. Sebelumnya ia masih memikirkan resiko keamanan dan kebersihan yang dijamin oleh para pemasang kawat gigi yang menjadi referensinya. Namun setelah berpikir kembali ia memutuskan untuk memasang kawat gigi dengan harga yang lebih murah saja. Pada saat datang ia mengungkapkan langsung dilayanani dengan baik oleh tukang gigi, dan ia melihat bahwa alatnya sama saja seperti dokter gigi. Ruangannya pun tidak jauh berbeda dengan dokter gigi. Tidak butuh waktu yang lama hanya sekitar 30 menit saja kawat gigi sudah dipasang. Ia mengungkapkan cukup rapih dalam pemasangan. Untuk beradaptasi dengan menggunakan kawat gigi cukup sulit, apalagi ketika akan mengkonsumsi makanan, terasa linu, namun lama kelamaan terbiasa dengan penggunaan kawat gigi tersebut. Tukang gigi pun menyarankan setiap bulan untuk penggantian karet. EH mengungkapkan tidak mengetahui aturan terkait dengan tukang gigi"

Narasumber ketujuh yaitu DW ia mengungkapkan: "Ia menggunakan kawat gigi sejak 3 bulan terakhir ini. Ia memasang kawat gigi pada tukang gigi, karena dinilai lebih terjangkau harganya. Pemilihan harga yang terjangkau menjadi faktor utama DW menentukan pemasangan kawat gigi di tukang gigi. Ia menggunakan kawat gigi hanya untuk fashion saja. Tidak pernah ada keluhan atau kendala yang ia keluhkan ketika menggunakan kawat gigi. Namun pernah sekali pada saat ia menggunakan kawat gigi ia memakan makanan yang tergolong keras sehingga menimbulkan karet kawat giginya terlepas. Pada saat itu ia mengeluhkan mengalami kesakitan selama 3 hari. Setelah itu ia kembali lagi ke tukang gigi untuk mengenakan kawat gigi yang baru. Ketika ditanya soal merasa aman atau tidak menggunakan kawat gigi di tukang gigi ia menjawab ia merasa aman. Ketika ditanya apakah DW mengetahui aturan yang terkait dengan tukang gigi, ia menjawab bahwa tidak mengetahui aturan tersebut".

Berdasarkan uraian di atas, dapat disimpulkan dari ketujuh konsumen pengguna jasa tukang gigi bahwa pertimbangan harga menjadi faktor utama yang menentukan masyarakat dalam memilih menggunakan jasa tukang gigi, namun masyarakat tidak memikirkan resiko yang akan terjadi apabila dilakukan oleh orang yang tidak berkompeten. Seperti diketahui bahwa tukang gigi mendapatkan ilmu dan keahliannya secara turun temurun. Bukan didapat melalui pendidikan di perguruan tinggi. Jika melihat dari hal tersebut maka perlindungan hukum bagi pihak konsumen. Pengawasan hukum suatu bidang yang tidak terpisahkan dari aktivitas bisnis yang sehat. Dalam bisnis yang sehat terdapat keseimbangan perlindungan hukum antara pelaku usaha dan konsumen. Tidak ada keseimbangan hukum antara konsumen dan pelaku usaha menyababkan konsumen dalam posisi yang lemah. Maka konsumen sering menganggap dirugikan oleh pelaku usaha yang merupakan akibat dari suatu hubungan hukum, maupun akibat adanya perbuatan melawan hukum yang timbul oleh pelaku usaha. Kondisi demikianlah yang perlu ditingkatkan upaya dalam melindungi hak-hak konsumen dan dapat terpenuhi maupun ditegakkan. Konsumen disini yaitu seseorang yang menggunakan jasa tukang gigi dan dan 
pelaku usaha adalah tukang gigi.

Perbuatan yang dilakukan oleh tukang gigi mustahil tidak tmenimbulakan suatu kesalahan maupun kelalaian dalam melakukan setiap praktiknya yang menimbulkan pengaruh besar dari akibat yang ditimbulkan. Untuk meminimalisir akibat-akibat yang muncul dari kesalahan pelaku usaha yang dapat melukai atau merugikan konsumen, maka dapat dilihat pada Pasal 8 UndangUndang Nomor 8 Tahun 1999 tentang Perlindungan Konsumen. Jika dilihat dari Pasal tersebut maka ada larangan yang diberlakukan bagi pelaku usaha dalam menjalankan usahanya agar tercipta keseimbangan antara pelaku usaha dan konsumen.

\section{Pengawasan Peraktik Tukang Gigi Oleh Dinkes Kota Bandar Lampung}

Seperti pada prinsip pembangunan yang menyatakan bahwa pembangunan dilakukan bersama masyarakat dengan pemerintah oleh karena itu merupakan tanggung jawab bersama, melalui peraturan dan pengawasan oleh pemerintah, dengan tujuan pembangunan nasional dapat dicapai dengan baik. Upaya pemerintah dalam melindungi konsumen dari produk yang merugikan dapat dilakukan dengan cara mengatur, mengawasi, serta mengendalikan produksi, distribusi dan peredaran produk sehingga konsumen tidak merasa dirugikan, baik kesehatannya maupun keuangannya. Dalam mengontrol praktik tukang gigi tertuang pada Pasal 10 Permenkes Nomor 39 Tahun 2014 tentang Pembinaan, Pengawasan dan Perizinan Pekerjaan Tukang Gigi. Pembinaan yang dilakukan oleh pemerintah daerah merujuk pada Pasal 178 Undang-Undang Nomor 36 Tahun 2009 tentang Kesehatan yang menyatakan bahwa pemerintah dan pemerintah daerah melakukan pembinaan terhadap masyarakat dan setiap penyelenggara kegiatan yang berhubungan dengan sumber daya kesehatan di bidang kesehatan dan upaya kesehatan. Selain itu, Dinkes Kota Bandar Lampung harus melakukan pengawasan terhadap masyarakat dan setiap pelaku kegiatan yang bersangkutan dengan sumber daya di bidang kesehatan dan upaya kesehatan. Pengawasan merujuk pada Pasal 182 Undang-Undang Nomor 36 Tahun 2009 tentang Kesehatan.

Dari hasil wawancara dengan Nirwansyah, staf Sesi Pelayanan Kesehatan Primer dan Tradisional di Dinas Kesehatan Kota Bandar Lampung, ia mengungkapkan:

"Bahwa masih terdapat banyak tukang gigi di Kota Bandar Lampung. Banyaknya tukang gigi tersebut belum terdata oleh Dinkes Kota Bandar Lampung. Dinas Kesehatan sendiri tidak mengetahui secara pasti berapa jumlah tukang gigi yang ada di Bandar Lampung, karena belum secara resmi melakukan pendataan. Nirwansyah mengaku, bahwa tukang gigi belum terjamah oleh Dinas Kesehatan. Mengenai perizinan, pihak Dinkes Kota Bandar Lampung belum mengeluarkan Surat Izin Praktik bagi tukang gigi, serta praktik tukang gigi sering berpindah-pindah. Nirwansyah juga mengungkapkan bahwa selama ini belum ada pembinan ataupun pengawasan yang dilakukan oleh Dinkes Kota Bandar Lampung terhadap tukang gigi. Tetapi untuk selanjutnya akan segera kami lakukan dimulai dari pendataan dan pengadaan sosialisasi untuk tukang gigi yang ada di Bandar Lampung. Sekilas kami perhatikan sepertinya dalam melakukan pekerjaan tukang gigi tidak mengikuti aturan yang terkait dengan pekerjaannya yaitu Peraturan Menteri Kesehatan Nomor 39 Tahun 2014 tentang Pembinaan, Pengawasan dan Perizinan Pekerjaan Tukang Gigi. Apabila melanggar aturan yang telah ditetapkan, maka pemerintah akan memberikan sanksi, seperti teguran lisan, teguran tertulis, dan akan diberhentikan praktik pelayanan kepada masyarakat apabila tak sesuai dengan aturanaturan yang berlaku. Dinas Kesehatan juga mengungkapkan masalah yang dihadapi apabila dalam melakukan pembinaan maupun pengawasan terhadap praktik tukang gigi karena pemerintah pusat saat ini dalam keadaan pasif kepada pemerintah daerah, oleh sebabnya Dinkes Kota Bandar Lampung sendiri belum dapat memberikan pembinaan ataupun pengawasan terhadap tukang gigi, karena dianggap tukang gigi buka merupakan program mendesak seperti halnya program kesehatan ibu dan anak ataupun pencegahan penyakit menular. Praktik tukang gigi dikategorikan dalam program pengembangan Dinas Kesehatan".

Upaya yang dapat dilakukan pemerintah dalam melindungi masyarakat dari praktik jasa tukang gigi yang dapat merugikan dapat dilakukan melalui pembinaan atau pengawasan oleh Dinas Kesehatan Daerah setempat sehingga konsumen mendapat pelayanan yang bermutu dan aman bagi kesehatan. Dinas Kesehatan setempat dapat melakukan tindakan administratif 
apabila dalam melakukan praktik tidak sesuai dengan peraturan yang ditetapkan, yang terdapat dalam Pasal 11 Peraturan Menteri Kesehatan Nomor 39 Tahun 2014 tentang Pembinaan, Pengawasan dan Perizinan Pekerjaan Tukang Gigi, yaitu: surat teguran, pencabutan izin sementara dan pencabutan izin tetap. Penulis berpendapat bahwa sanksi administratif yang ditetapkan oleh Peraturan Menteri Kesehatan Nomor 39 Tahun 2014 tentang Pembinaan, Pengawasan dan Perizinan Pekerjaan Tukang Gigi dinilai lebih efektif dibandingkan sanksi lainnya. Hal ini dikarenakan sanksi administratif dapat dilaksanakan secara langsung dan sepihak kepada atau pelaku usaha. Sanksi administratif selalu berkaitan dengan pencabutan izinan yang diberikan oleh pemerintah daerah Kabupaten/Kota, dengan demikian jika suatu pelanggaran yang dilakukan oleh pelaku usaha maka pemerintah terkait dapat melakukan pencabutan dan menghentikan kegiatan usahanya.

\section{Penutup}

Tanggung jawab tukang gigi dalam peraturan perundang-undangan yang berlaku pada saat ini hanya membuat gigi replika lepasan sebagian atau penuh yang terbuat dari bahan heat curing acrylic dengan memenuhi kriteria dalam kesehatan dan memasang gigi replika lepasan sebagian atau penuh dengan bahan heat curing acrylic dengan tidak menutup sisa atau bagian akar gigi. Namun dalam praktiknya tukang gigi sering kali melakukan pekerjaan lain yang melewati batas kewenangannya seperti pemasangan kawat gigi, pembersihan karang gigi, serta vaneer gigi (pewarnaan kawat gigi). Sehingga dalam melakukan praktiknya tukang gigi tidak dapat dipertanggung jawabkan perbuatannya. Bahwa konsumen atau pengguna jasa belum terlindungi dari adanya praktik tukang gigi. Konsumen dalam penggunaan jasa tukang gigi hanya dapat menikmati hasil dari pekerjaan tukang gigi, akantetapi tidak mengetahui adanya perlindungan hukum bagi konsumen apabila dalam praktiknya tukang gigi melanggar aturan yang telah ditetapkan oleh pemerintan. Dalam melakukan praktiknya tukang gigi belum sepenuhnya terlindungi oleh peraturan yang telah berlaku. Ketidaktahuan terhadap aturan yang tersebut, menyebabkan tukang gigi dalam melakukan praktiknya dan melakukan kegiatan yang diluar batas kewenangan yang telah ditetapkan. Sehingga perlindungan hukum terhadap tukang gigi tidak dapat diterapkan. Belum ada pengawasan yang dilakukan oleh Dinkes Kota Bandar Lampung terhadap praktik jasa tukang gigi. Hal ini ditandai oleh tidak adanya surat izin yang terdaftar dari Dinas Kesehatan terhadap praktik tukang gigi di Kota Bandar Lampung. 


\section{A. Buku}

\section{DAFTAR PUSTAKA}

Miru, Ahmadi. (2013). Prinsip-prinsip Perlindungan Hukum Bagi Konsumen di Indonesia. Jakarta: RajaGrafindo Persada.

Sidabalok, Janus. (2010). Hukum Perlindungan Konsumen di Indonesia. Citra Aditya Bakti.

Sulandari, JPC. Heryumani. (2008). Buku Ajar Ortodonsia I KOG I. Yogyakarta: Universitas Gadjah Mada.

\section{B. Jurnal}

Iin sundari, Pocut aya Sofya, dan Milati Hanifa, "Studi Kekuatan FleksuralAntara Resin Akrilik Heat Cured dan Termoplastik Nilon Setelah Direndam Dalam Minuman Kopi Uleekareng (Coffe Robusta)", Universitas Syia Kuala, (2016).

Lendrawati, "Motivasi Masyarakat Dalam Memelihara dan Mempertahankan Gigi", Fakultas Kedokteran Gigi Universitas Andalas Padang.

Marsela, Annisa, "Aktivitas Jasa Pemasangan Kawat Gigi", JOM FISIP, Vol. 2 No. 2, (2015).

Sulmayeti, "Perilaku Konsumsi Pemakaian Kawat Gigi Non Medis", JOM FISIP, Volume 2 No.1, (2015).

Kasmawati, "Perlindungan Hukum Bagi Konsumen Terhadap Tegangan Tinggi Listrik di Bandar Lampung", Fiat Justitia Jurnal Ilmu Hukum.

\section{Internet}

www.beritasatu.com/nasib-tukang-gigi/47915-inilah-sejarah-tukang-gigi-di-indonesia.html.

www.shinymiledentalclinic.com. Sejarah penemuan kawat gigi. Diakses pada 31 Agustus 2017 pukul 08.43 WIB. 
